\title{
Effect of Bentazon on Growth and Physiological Responses of Marine Diatom: Chaetoceros gracilis
}

\author{
Annick Hourmant ${ }^{1,{ }^{*}}$, Anis Amara ${ }^{1}$, Patrick Pouline ${ }^{1}$, Gaël Durand ${ }^{2}$, Geneviève Arzul ${ }^{3}$, Françoise \\ Quiniou $^{3}$
}

\author{
${ }^{1}$ Laboratory of Biotechnology and Plant Physiology, UFR Sciences et Techniques, C.S. 93837, 29238 Brest \\ Cedex 3, France. \\ ${ }^{2}$ IDHESA, B.P. 52, 29280 Plouzané, France. \\ ${ }^{3}$ Ifremer, Department of Biogeochemistry and Ecotoxicology, 29280 Plouzané, France
}

*: Corresponding author : Annick Hourmant, Tel. +33 2980162 47, Fax : +33 2980171 70, email address : Annick.Hourmant@univ-brest.fr

\begin{abstract}
:
The herbicide bentazon (CASRN 25057-89-0) is extensively used in agriculture in Brittany (France) to replace atrazine. Bentazon is not readily adsorbed by soil and therefore it enters adjacent freshwater ecosystems, making its way to estuarine and marine waters areas. Information regarding its effects on marine ecosystems is scarce. Phytotoxicity assessments were conducted in the laboratory on the common diatom Chaetoceros gracilis using both the active ingredient and its formulated product (Basamaïs). The 3 day $\mathrm{EC}_{50}$ using cell counts were, respectively, $150 \mathrm{mg} / \mathrm{L}$ and $60 \mu \mathrm{g} / \mathrm{L}$ for bentazon active ingredient and for bentazon-formulated while cellular volume was increased. Although bentazon is known as a photosystem II inhibitor, it produced an increase of pigment (chlorophylls a, c, and carotenoids) content, ATP synthesis, rates of photosynthesis and respiration, and TBARS formation. Therefore, pigments cannot be used as biomarkers of toxicity. Algal cell recovery from bentazon effects occurred after 6-9 days, suggesting a tolerance mechanism.
\end{abstract}

Keywords: ATP, Bentazon, Carotenoids, Chaetoceros gracilis, Chlorophylls, Growth, Marine diatom, Photosynthesis 
Funding sources: This research was financed by grants from the Ministère de l'Ecologie et du Développement Durable through the program « Evaluation et réduction des risques liés à l'utilisation des pesticides ».

Formal assurance: We certify that experiments needed for the work described in this manuscript have not required any study involving humans or animals.

\section{Introduction}

Weed control in maize crops has long relied on the use of substituted triazines such as atrazine. The use of this herbicide is now forbidden in France and, bentazon (CAS registry number 25057-89-0), a postemergence herbicide like atrazine, is used as a substitute. Bentazon is not readily adsorbed by soil (Abernathy and Wax 1973), and therefore it enters adjacent freshwater ecosystems, making its way to estuarine and marine waters areas from spraying, leaching and run-off. This herbicide has been detected occasionally in estuaries (up to $562 \mathrm{ng} \mathrm{L}^{-1}$ ) and in seawater, salinity 33 (up to $83 \mathrm{ng} \mathrm{L}^{-1}$ ) (IDHESA, personal communication).

The potential threat of bentazon on aquatic ecosystems has raised considerable concern, and the toxicity of this compound on fish, Daphnia, freshwater algae (AGRITOX 2006; Tomlin 1997) and Lemna (Michel et al. 2004) has been studied. Up to now, toxicity data for herbicides concerning marine ecosystems are relatively sparse (Unseal 1992; Pennington and Scott 2001; Tsui and Chu 2003; Arzul et al. 2006). Microalgae play an important role in the equilibrium of aquatic ecosystems, being the first level of trophic chain to produce organic matter and oxygen. Due to their highly sensitive nature, microalgae are claimed as the possible early indicator of deteriorating environmental conditions (McCormick and Cairns 1994). The selected algal species is the diatom Chaetoceros gracilis, representative of the field communities of concern. Bentazon, like most photosynthesisinhibiting herbicides, competes with plastoquinone at its binding site on the D1 protein, blocking electron transport from photosystem II, resulting in photosynthesis inhibition and generation oxidative stress in sensitive species (Cremlyn 1991; Scalla and Gauvrit 1991; Macedo et al. 2008).

The present investigation was aimed to elucidate the effect of bentazon alone and in formulation on Chaetoceros gracilis growth, photosynthetic activity, respiration, ATP synthesis and thiobarbituric acid reactive-substances as important physiological parameters in the evaluation of herbicide toxicity.

\section{Materials And Methods}

\section{Microalgal culture}

Chaetoceros gracilis was obtained from SATMAR (Saint-Vaast-La Hougue, France) and was maintained in a f/2 growth medium (Guillard and Ryther 1962). The inoculum $\left(0.2 \times 10^{4}\right.$ to $10^{4}$ cells $\mathrm{ml}^{-1}$ ) was taken from the growth logarithmic phase and cultures were grown in $1 \mathrm{~L}$ Pyrex glass bottles containing $500 \mathrm{ml}$ of filtered seawater enriched as shown in Table 1 to obtain a medium simulating post winter conditions in temperate coastal areas (Le Pape et al. 1995). In parallel, a few experiments were performed with $C$. gracilis cultivated in $f / 2$ medium to assure sufficient biomass for some physiological experiments. After autoclaving, sterilized vitamins, $\mathrm{Na}_{2} \mathrm{SiO}_{3}$, Fe-ethylene diamine tetracetic acid (Fe-EDTA) and metal traces according to Guillard and Ryther (1962) were added. Non-axenic microalgal cultures were maintained at $18 \pm 2{ }^{\circ} \mathrm{C}$ under a $16 \mathrm{~h}$ photoperiod with $45 \mu \mathrm{mol} \mathrm{m} \mathrm{m}^{-2} \mathrm{~s}^{-1}$ of photosynthetically active radiations (PAR), controlled with a light meter (LiCor, model Li 250). 


\section{Pesticide}

Bentazon (3-(1-isopropyl-1H)-2,1,3-benzothiadiazin-4-(3H)-one 2,2-dioxyde) was purchased from Riedel-de-Häen. A stock solution was prepared by dissolving $100 \mathrm{mg}$ per liter of artificial seawater and sterilized by filtration through a $0.22 \mu \mathrm{m}$ membrane (Dynagard). A commercial formulation of bentazon : Basamaïs (403 $\mathrm{g}$ active molecule per $\mathrm{Kg}$ ) (BASF AGRO SAS) was also assayed. The effective bentazon concentration was checked in sub-samples. Chemical analyses were performed at the "IDHESA, Brest", using High Performance Liquid Chromatography coupled with a triple quadripole mass spectrometer. The samples were stored frozen in previously burnt glass bottles until use, which was no more than one month.

\section{Growth measurement}

The cellular concentration was checked by microscope counting. The $\mathrm{EC}_{50}$ (concentration required to cause a 50\% reduction in growth) were calculated 3 days after algae inoculation. For each culture, the growth rate was calculated after log transformation and the Excel Macro REGTOX, was applied to the growth rate to obtain the $\mathrm{EC}_{50}$ according to Vindimian et al. (1983). The NOEC (no observed effect concentration) was estimated using the DEBtox model described by Kooijman et al. (1996).

The cell size was determined from the length measures made by microscopic analyses of lugol-fixed cells. The microscope was a Zeiss Axiovert 135 equipped with a custom image analyser software, allowing morphometric and cell counting analyses (Lunven et al. 2003).

\section{Measurement of pigments}

Diatom cells were harvested by filtration through a $0.45 \mu \mathrm{m}$ GV membrane filter (Millipore) and pigments were extracted with $100 \%$ methanol at $65^{\circ} \mathrm{C}$ during $20 \mathrm{~min}$. After cooling, the methanolic solution was centrifuged $(2,500 \mathrm{~g}, 10 \mathrm{~min})$ and its absorbance was measured at 470, 510, 630 and $664 \mathrm{~nm}$ (spectrophotometer Hitachi, U 2000). Concentrations of chlorophylls ( $\mathrm{a}$ and $\mathrm{c}$ ) and total carotenoids were determined according to the methods of Jeffrey and Humphrey (1975) and Gala and Giesy (1993) respectively.

\section{Photosynthetic and respiration rates}

Gross photosynthesis and dark respiration were determined as $\mathrm{O}_{2}$ exchanges at $20{ }^{\circ} \mathrm{C}$ using a Clark-type electrode (YSI 53 Oxygen Monitor). Photosynthesis was measured under a 140 $\mu \mathrm{mol} \mathrm{m} \mathrm{mec}^{-1}$ PAR.

\section{Determination of ATP}

The ATP content was determined using an ATP bioluminescent assay kit (Perkin Elmer $®$ ). $100 \mu \mathrm{l}$ of the algal suspension were injected directly in a well of a 96-well plate and added with $50 \mu \mathrm{l}$ cell lysis solution. The plates were covered with pre-cut acetate tapes (Dynatech $\left.{ }^{\circledR}\right)$ and agitated for $5 \mathrm{~min}(700 \mathrm{rpm})$. After addition of $50 \mu \mathrm{l}$ luciferin-luciferase, plates were shaked for $5 \mathrm{~min}$ and incubated in the dark (10 min). Luminescence measurements were performed at the luminometer (Victor, Perkin Elmer®) using a 10s integration time. The luminescence data (relative light units) were converted using a 
calibration curve obtained with ATP dissolved in sterile seawater. This technique allows quantification of ATP down to 70 cells of algae.

\section{Lipid peroxidation}

Lipid peroxidation was estimated following the methods of Minotti and Aust (1987) and Iturbe-Omaetxe et al. (1998). Diatom cells were harvested by filtration through a $0.45 \mu \mathrm{m} \mathrm{GV}$ membrane filter (Millipore) and lipid peroxides were extracted with $3.5 \mathrm{ml}$ of $5 \%$ metaphosphoric acid and $70 \mu \mathrm{l}$ of $2 \%$ butyl hydroxytoluene (in ethanol). After $30 \mathrm{~min}$ at $4^{\circ} \mathrm{C}$, homogenate was centrifuged at 5,000 rpm for $20 \mathrm{~min}$. The chromogen was formed by mixing $1 \mathrm{ml}$ supernatant with $100 \mu \mathrm{l} 2 \%$ butyl hydroxytoluene, $0.5 \mathrm{ml}$ of $1 \%(\mathrm{w} / \mathrm{v})$ thiobarbituric acid (in $50 \mathrm{mM} \mathrm{NaOH}$ ) and $0.5 \mathrm{ml}$ of $25 \% \mathrm{HCL}$. The reaction mixture was heated for $30 \mathrm{~min}$ at $95^{\circ} \mathrm{C}$ and then was cooled rapidly on ice. The chromogen was extracted by adding $1.5 \mathrm{ml}$ of 1-butanol. After 30 s vortexing, the organic phase was separated by centrifugation $(5,000$ $\mathrm{rpm}, 5 \mathrm{~min}$ ) and the thiobarbituric acid reactive-substances (TBARS) determined by measuring the absorbance at $532 \mathrm{~nm}$ (spectrophotometer Hitachi, $U$ 2000). The concentration of TBARS was calculated by using the extinction coefficient of $155 \mathrm{mM}^{-1} \mathrm{~cm}^{-1}$.

\section{Statistical analyses}

All experiments were conducted three or more times, data were statistically analysed by a one-way analysis of variance (ANOVA) and, when differences observed were significant, means were compared by the multiple range Duncan test. Significant differences at a level of significance of $0.05(P<0.05)$ are represented by an asterisk $\left(^{*}\right)$. Data are given as means values \pm standard errors of the means

\section{Results}

\section{Effect of bentazon and formulated product (Basamaïs) on growth}

Growth of $C$. gracilis was inhibited by the addition of bentazon to the post winter medium and, the inhibition increased with increasing concentrations of both pure bentazon (from 0 to $200 \mathrm{mg} \mathrm{L}^{-1}$ ) (Fig.1) and formulated product (from 0 to $100 \mathrm{gg} \mathrm{L}^{-1}$ ) (Fig. 2). The 3 day NOEC values for cell density were estimated to be respectively $10 \mathrm{mg} \mathrm{L}^{-1}$ and $10 \mu \mathrm{g} \mathrm{L}^{-1}$ (Table 2) whereas the calculated $\mathrm{EC}_{50}$ values were $150 \mathrm{mg} \mathrm{L}^{-1}$ and $60 \mathrm{\mu g} \mathrm{L}^{-1}$. After a 3 day exposure to $100 \mathrm{\mu g} \mathrm{L}^{-1}$ formulated product, the cell size was significantly increased (Fig. 3) and the mean sizes were respectively for the control and the treated cells 5.15 and $5.95 \mu \mathrm{m}$. Because the formulated product was 2500 more toxic, the following experiments were conducted with the formulation.

Fig. 4 shows the time course effect of the bentazon formulated product on the growth of $C$. gracilis cultivated in post winter medium (A) and f/2 medium (B). After 3 days, the inhibitory effect of the herbicide, that was also observed in $\mathrm{f} / 2$ medium though at higher dose, tends to progressively disappear in both media.

\section{Effect of bentazon formulated product on pigment content}

The time responses of pigment alterations in $C$. gracilis cultured in the post winter medium are summarized in Fig.5. In control cultures, after a large increase in chlorophylls (Fig. 5A) and carotenoids (Fig. 5B) contents occurring after 2 days, the pigment level returned to its 
initial value and then declined slightly. Compared with the control, the addition of $50 \mu \mathrm{g} \mathrm{L}^{-1}$ bentazon produced after the 2-day exposure a 30-40\% inhibition of the pigment content and significantly increased it afterward. The bentazon stimulation, maximal after 3 days of exposure (+ 35 to $69 \%)$, tends to attenuate with time. The content of chlorophylls a and $c$ and carotenoids fluctuated in the same way.

When $C$. gracilis was cultivated in a $\mathrm{f} / 2$ medium, pigment contents were higher than in post winter conditions and, addition of $50 \mathrm{\mu g} \mathrm{L}^{-1}$ bentazon produced also a stimulation in pigment contents (+ 31 to $56 \%$ ) that occurred after one day of exposure and to a less extent after 2 days (Table 3 ).

\section{Effect of bentazon formulated product on photosynthetic and respiration rates}

The effects of bentazon on the photosynthetic and respiration rates of $C$. gracilis grown in a post winter medium are shown in Table 4. Gross photosynthesis and respiration were significantly increased after 3 days of exposure with bentazon (40 and $\left.50 \mu \mathrm{g} \mathrm{L}^{-1}\right)$. Same results were obtained with $C$. gracilis grown in $\mathrm{f} / 2$ medium (not reported).

\section{Effect of bentazon formulated product on ATP content}

The dose and time responses of ATP changes in C. gracilis are summarized in Fig. 6. When C. gracilis was grown in a post winter medium, a peak in ATP production was observed after 2 days of culture; this peak was amplified by the presence of 50 and $100 \mathrm{\mu g} \mathrm{L}^{-1}$ bentazon giving respectively rise to $58 \%$ and $233 \%$ stimulation. Table 3 reports the results obtained with a f/2 medium. The presence of $50 \mathrm{\mu g} \mathrm{L}^{-1}$ bentazon produced after 1 and 2 day incubation a significant increase in ATP $(+49 \%$ and $+43 \%$, respectively) with respect to the control $(100 \%)$.

\section{Effect of bentazon formulated product on TBARS formation}

TBARS formation is considered the general indicator of lipid peroxidation. Measurements were carried out under $\mathrm{f} / 2$ medium to get a sufficient cellular biomass. TBARS level was significantly increased (+47\%) in C. gracilis after a 2-day exposure to $50 \mathrm{\mu g} \mathrm{L}^{-1}$ bentazon (Table 5).

\section{Discussion}

The sensitivity of C. gracilis to bentazon and its formulation (Basamaïs) was examined, and the influence of the growth medium on the Basamaïs toxicity was studied.

The 3 day $\mathrm{EC}_{50}$ for the formulated product of bentazon was $60 \mathrm{\mu g} \mathrm{L}^{-1}$ and NOEC $10 \mu \mathrm{g} \mathrm{L}^{-1}$. These values are three orders of magnitude below the pure compound's $\mathrm{EC}_{50}$ and NOEC, confirming the importance of evaluating the potential toxicity of complete formulation, rather just the toxicity of active component because it is the formulation that goes to the marine ecosystem (Caux et al. 1996; Oakes and Pollack 2000; Grisolia et al. 2004). The $\mathrm{EC}_{50}$ of the pure molecule $\left(150 \mathrm{mg} \mathrm{L}^{-1}\right)$ is intermediate between the values reported for Chlorella (279 $\mathrm{mg} \mathrm{L}^{-1}$ ) and Ankistrodesmus (47.5 $\mathrm{mg} \mathrm{L}^{-1}$ ) or Skeletonema (24 $\mathrm{mg} \mathrm{L}^{-1}$ ) (AGRITOX 2006; Tomlin 1997; Macedo et al. 2008). By contrast, the $E C_{50}$ of the formulated bentazone for $C$. gracilis $\left(60 \mu \mathrm{g} \mathrm{L}^{-1}\right)$ is three orders of magnitude below the 3 or 4 day $\mathrm{EC}_{50}$ reported for Pseudokirchneriella (34.8 $\mathrm{mg} \mathrm{L}^{-1}$ ) and Ankistrodesmus (30 mg L${ }^{-1}$ ) (AGRITOX, 2006). These results suggest that adjuvants or formulation additives work to exaggerate bentazon absoption by phytoplankton cells and that formulated bentazon displays a higher toxicity 
towards the marine diatom $C$. gracilis than towards freshwater algae. This is in agreement with data about isoproturon reported by Arzul et al (2006). Mean cell size in diatoms generally decreases at each cell division during the phase of vegetative growth (Round et al. 1990). Therefore, increase by bentazon of the mean cell size reflects the inhibition of cell division observed after a 3 day exposure.

Growth rate is often closely related to energy production. Interestingly, bentazon increases oxygen exchanges and markedly amplifies the increase of ATP content that occurs in the control at days 2-3 while growth inhibition was clearly observed. This may suggest that ATP produced was not used to cope growth requirements and, as a consequence accumulates within the cell.

Because the increase in pigment content that occurs in control at day 2, was delayed in the presence of bentazon, the pigment per cell increased markedly at day 3 while growth inhibition was observed. Examples of triazine-induced increases of algal chlorophyll content have been reported in freshwater algae (Mayer and Jensen 1995; Rioboo et al. 2002). The mechanism of toxicity is therefore probably not an interference with the formation or maintenance of pigments but with other essential processes. The increase in pigment content may explain the higher photosynthesis activity observed after a 3-day exposure to 50 $\mu \mathrm{g} \mathrm{L}^{-1}$ bentazon in spite of bentazon being a photosynthesis-inhibiting herbicide. However, if the treatment with bentazon $\left(100 \mu \mathrm{g} \mathrm{L}^{-1}\right)$ is only $30 \mathrm{~min}$, it provokes a $34 \%$ inhibition of photosynthesis whereas respiration remained unchanged (data not shown); this is in accordance with what is expected concerning this herbicide.

As shown on growth curve, after a 3-4 day bentazon exposure, the cells of $C$. gracilis tend to increase the growth rate after a strong inhibitory growth period. In parallel, ATP and pigment content approaches that of the control. This may be due to an active bentazon metabolism. Preliminary results indicate that bentazon was partially hydroxylated by $C$. gracilis into 8hydroxyl bentazon and, the bentazon detoxification is a key factor related to a tolerance mechanism. Such results have been reported in many tolerant plant species including crops and weeds (Wu and Wang 2003 and references therein). Based on these results, one can say that values obtained only after 3 or 4 days of herbicide exposure can give a partial view of the facts occurring in a marine ecosystem.

Although the $\mathrm{f} / 2$ medium allows a higher synthesis of pigments and ATP, the physiological responses to bentazon were similar to what was observed in post winter conditions i.e. reduction of growth, increase of pigment and ATP contents. These data do not show any influence of the growth nutritional medium on the toxicity of bentazon.

TBARS are indicators of lipid peroxidation that produces aldehydes, mainly malondialdehyde and 4-hydroxynonenal (Lagadic et al. 1997). Recent papers report that unsaturated diatomderived aldehydes (Adolph et al. 2004) and 4-hydroxynonenal (Monneypenny and Gallagher 2005) induce antiproliferative activity in a broad range of organisms. Increased production of TBARS and therefore of 4-hydroxynonenal under a 2-day exposure to bentazon might contribute to reduce the growth of $C$. gracilis as observed. More experiments are needed to confirm this hypothesis.

\section{Conclusions}

Exposure for 3 days of $C$. gracilis to the photosystem II inhibiting herbicide bentazon reduces the cell density while increases the cell volume and, toxicity of the formulation was markedly higher. This herbicide increases pigment content and thereby photosynthesis and ATP generation. The results suggest that bentazon may affect pigments and growth differently and, phytoplankton chlorophyll a cannot be used as a biomarker of toxicity. Algal cell recovery from bentazon effects occurred after 6-9 days suggesting a tolerance mechanism. Based on these results, one can say that values obtained only after 3 or 4 days of herbicide exposure can give a partial view of the facts occurring in a marine ecosystem. 
This research was financed by grants from the Ministère de l'Ecologie et du Développement Durable, through the program «Evaluation et réduction des risques liés à l'utilisation des pesticides ».

\section{References}

Abernathy, J.R., and Wax, L.M. 1973. Bentazon mobility and adsorption in twelve Illinois soils. Weed Sci. 21:222-227.

Adolph, S., Bach, S., Blondel, M., Cueff, A., Moreau, M., Pohnert, G., Poulet, S.A., Wichard, T., and Zuccaro, A. 2004. Cytotoxicity of diatom-derived oxylipins in organisms belonging to different phyla. J. of Exp. Biol. 207:2935-2946.

AGRITOX, Base de données INRA/ Ministère de l'Agriculture et de la Pêche. Versailles, FR 2006.

Arzul, G., Quiniou, F., and Carrie, C. 2006. In vitro test-based comparison of pesticideinduced sensitivity in marine and freshwater phytoplankton. Toxicol. Mech. Meth.16:1-7.

Caux, P. Y., Ménard, L ., and Kent, R. A. 1996. Comparative study of the effects of MCPA, butylate, atrazine, and cyanazine on Selenastrum capricornutum. Environ. Pollut. 92 :219225.

Cremlyn, R.J. 1991. Agrochemicals : preparation and mode of action. J. Wiley and Sons Inc., New York, USA.

Gala, W.R., and Giesy, J.P. 1993. Using the carotenoid biosynthesis inhibiting herbicide, fluridone, to investigate the ability of carotenoid pigments to protect algae from the photoinduced toxicity of anthracene. Aquat. Toxicol. 27:61-70.

Grisolia, C. K., Bilich, M.R., and Formigli, L.M. 2004. A comparative toxicologic and genotoxic study of the herbicide arsenal, its active ingredient imazapyr, and the surfactant nonylphenol ethoxylate. Ecotoxicol. Environ. Saf. 59:123-126.

Guillard, R.R.L., and Ryther, J.H. 1962. Studies of marine planktonic diatoms Cyclotella nana Hustedt and Detonula confervacea Cleve. Can. J. Microbiol. 8:229-239.

Iturbe-Omaetxe, I., Escuredo, P.R., Arrese-Igor, C., and Becana, M. 1998. Oxidative damage in pea plants exposed to water deficit or paraquat. Plant Physiol. 116:173-181.

Jeffrey S.W., and Humphrey G.F. 1975. New spectrophotometric equations for determining chlorophyll $\mathrm{a}, \mathrm{b}, \mathrm{c}_{1}$ and $\mathrm{c}_{2}$ in higher plants, algae and natural populations. Bioch. und Physiol. der Pflanzen. 167:191-194.

Kooijman, S. A. L. M., Hansveit, A. 0., and Nyholm, N. 1996. No-effect concentrations in algal growth. Inhibition tests. Wat. Res. 30:1625-1632.

Lagadic, L., Caquet, T., Amiard, J.C., and Ramade, F. 1997. Biomarqueurs en écotoxicologie. Aspects fondamentaux. Masson ed. Paris, Milan, Barcelone.

Le Pape, O., Del Amo, Y., Cann, P., Ménesguen, A., Aminot, A., Quéguiner, B., and Tréguer, $P$. 1995. Résistance à l'eutrophisation d'un écosystème côtier enrichi : la rade de Brest. $3^{\text {èmes }}$ rencontres scientifiques internationales. Actes du colloque. 14-16 mars, Brest. Vol. 1, pp5979.

Lunven, M., Gentien, P., Kononen, K., Le Gall, E., and Daniellou, M.M. 2003. In situ video and diffraction analysis of marine particles. Estuarine, Coastal and Shelf Sci. 57:5-6.

Macedo R.S., Lombardi A.T., Omachi C.Y. and Rörig L.R., 2008. Effects of the herbicide bentazon on growth and photosystem II maximum quantum yield of the marine diatom Skeletonema costatum. Toxicol. in vitro, 22:716-722.

Mayer, P., and Jensen, J.F. 1995. Factors affecting results of algal toxicity tests. In : Institute for environmental science and technology. Technical University of Denmark, Lyngby.

McCormik, P.V., and Cairns, J.J. 1994. Algae as indicators of environmental change. J. Appl. Phycol. 6:509-526. 
Michel, M., Jonhson, R.D., Duke, S.O., and Scheffler, B.E. 2004. Dose-response relationships between herbicide with different modes of action and growth of Lemna pausicostata : an improved ecotoxicological method. Environ. Toxicol. Chem. 23:074-1079.

Minotti, G., and Aust, S.D. 1987. The requirement for iron (III) in the initiation of lipid peroxidation by iron (II) and hydrogen peroxide. J. Biol. Chem. 262:1098-1104.

Monneypenney, C.G. and Gallagher, E.P. 2005. 4-Hydroxynonenal inhibits cell proliferation and alters differentiation pathways in human fetal liver hematopoietic stem cells. Biochem. Pharmacol. 69:105-112.

Oakes, D.J., and Pollak. J.K. 2000. The in vitro evaluation of the toxicities of three related herbicide formulations containing ester derivates of 2,4,5-T and 2,4-D using submitochondrial particles. Toxicology, 151:1-9.

Pennington, P.L., and Scott, G.I. 2001. Toxicity of atrazine to the estuarine phytoplankter Pavlova sp.(Prymnesiophyceae) : increased sensitivity after long-term, low-level population exposure. Environ. Toxicol. Chem. 20:2237-2242.

Rioboo, C., Gonzalez, O., Herrero, C., and Cid, A. 2002. Physiological response of freshwater microalga (Chlorella vulgaris) to triazine and phenylurea herbicides. Aquat. Toxicol. 59:225-235.

Round, E. E., Crawford, R. M., and Mann, D. G. 1990. The diatoms - Biology \& morphology of the genera. Cambridge University Press, Cambridge.

Scalla, R., and Gauvrit, C. 1991. Mécanismes d'action phytotoxique des autres familles d'herbicides. In: Les herbicides: mode d'action et principes d'utilisation. ed. R. Scalla, INRA, pp. 115-191.

Tomlin, C.D.S. 1997. The pesticide manual. British crop protection council. The Royal Society of Chemistry. Cambridge, UK.

Tsui, M.T.K., and Chu, L.M. 2003. Aquatic toxicity of glyphosate-based formulations: comparison between different organisms and the effects of environmental factors. Chemosphere, 52:1189-1197.

Unseal, M., 1992. Effects of herbicides on the growth of marine phytoplancton. Proceedings of the FAO-UNEP-IOC workshop on the biological effects of pollutants on marine organisms. MAP Rech. Rep. Ser., 69:255-264

Vindimian, E., Robaut, C., and Fillion, G. 1983. A method for cooperative and non comparative binding studies using non regression analysis on a microcomputer. J. Appl. Biochem. 5:261-268.

Wu, C.M., and Wang, C.Y., 2003. Physiological study on bentazon tolerance in inbred corn (Zea mays). Weed Technol. 17:565-570.

\section{Tables}

\section{TABLE 1}

Nutrient composition of $f / 2$ medium and post winter conditions. Vitamins, Fe-EDTA, metals and silicium added according to Guillard and Ryther (1962).

\begin{tabular}{llc}
\hline & $\mathrm{NaH}_{2} \mathrm{PO}_{4}(\mu \mathrm{M})$ & $\mathrm{NaNO}_{3}(\mu \mathrm{M})$ \\
\hline $\mathrm{f} / 2$ medium & 36.3 & 880 \\
Post winter conditions & 0.36 & 23
\end{tabular}


TABLE 2

Effect of bentazon and formulated product (Basamaïs) on growth parameters of C. gracilis cultivated 3 days in post winter conditions.

\begin{tabular}{lll}
\hline & NOEC & $\mathrm{CE}_{50}$ \\
\hline $\begin{array}{l}\text { Bentazon } \\
\text { Basamaïs } \\
\text { (formulated bentazon) }\end{array}$ & $10 \mathrm{mg} \mathrm{L}^{-1}$ & $150 \mathrm{mg} \mathrm{L}^{-1}$ \\
& & $60 \mathrm{~g} \mathrm{~L}^{-1}$ \\
\hline
\end{tabular}

TABLE 3

Influence of $50 \mu \mathrm{g} \mathrm{L}^{-1}$ bentazon (Basamaïs) on the pigment and ATP content of $C$. gracilis grown for 1 and 2 days in a f/2 medium.

$$
\text { Pigments (ng. } \left.\quad 10^{6} \text { cells }^{-1}\right) \stackrel{\begin{array}{l}
\text { ATP } \\
\left(\text { pmoles } 10^{6} \text { cells }^{-1}\right)
\end{array}}{ }
$$

\begin{tabular}{lll}
\hline Chlorophylle a & Chlorophylle c & Carotenoids
\end{tabular}

\begin{tabular}{llcccc}
\hline 1 day & Control & $187 \pm 17$ & $120 \pm 12$ & $173 \pm 15$ & $119 \pm 13$ \\
& Bentazon & $291 \pm 26^{*}$ & $163 \pm 14^{*}$ & $227 \pm 21^{*}$ & $177 \pm 15^{*}$ \\
2 days & Control & $227 \pm 20$ & $144 \pm 14$ & & $205 \pm 9$ \\
& Bentazon & $294 \pm 27^{*}$ & $166 \pm 16$ & $242 \pm 25$ & $159 \pm 15^{*}$ \\
\hline
\end{tabular}

Means of 4 independent experiments \pm SD. * indicates a value significantly different from the control at $P<0.05$.

TABLE 4

Oxygen exchanges obtained in cultures of $C$. gracilis exposed to different concentrations of bentazon (Basamaïs) after 3 days in post winter conditions.

\begin{tabular}{lll}
$\begin{array}{l}\text { Bentazon } \\
\left(\mu \mathrm{g} \mathrm{L}^{-1}\right)\end{array}$ & $\mu \mathrm{h} \mathrm{h}^{-1} 10^{6}$ cells $^{-1}$ & \\
& Gross Photosynthesis & Respiration \\
\hline 0 & $14.83 \pm 1.2$ & \\
10 & $18.98 \pm 3.13$ & $4.02 \pm 0.45$ \\
40 & $25.69 \pm 2.85^{*}$ & $4.11 \pm 0.46$ \\
50 & $26.69 \pm 3.54^{*}$ & $5.35 \pm 0.49^{*}$ \\
& & $5.79 \pm 0.52^{*}$
\end{tabular}


Means \pm SD $(\mathrm{n}=6) . *$ indicates a value significantly different from the control at $P<0.05$.

TABLE 5

Change of TBARS in C. gracilis after a 2 days of exposure to $50 \mu \mathrm{g} \mathrm{L}^{-1}$ bentazon (Basamaïs) in a f/2 medium.

\begin{tabular}{ll}
\hline Control & Bentazon \\
\hline $9.10 \pm 0.65$ & $13.39 \pm 0.87(147 \%)$ \\
\hline
\end{tabular}

The values expressed in nmoles $10^{6}$ cells $^{-1}$ are means of three individual experiments. $n=3$ for \pm S.D., $P<0.05$

\section{Figures}

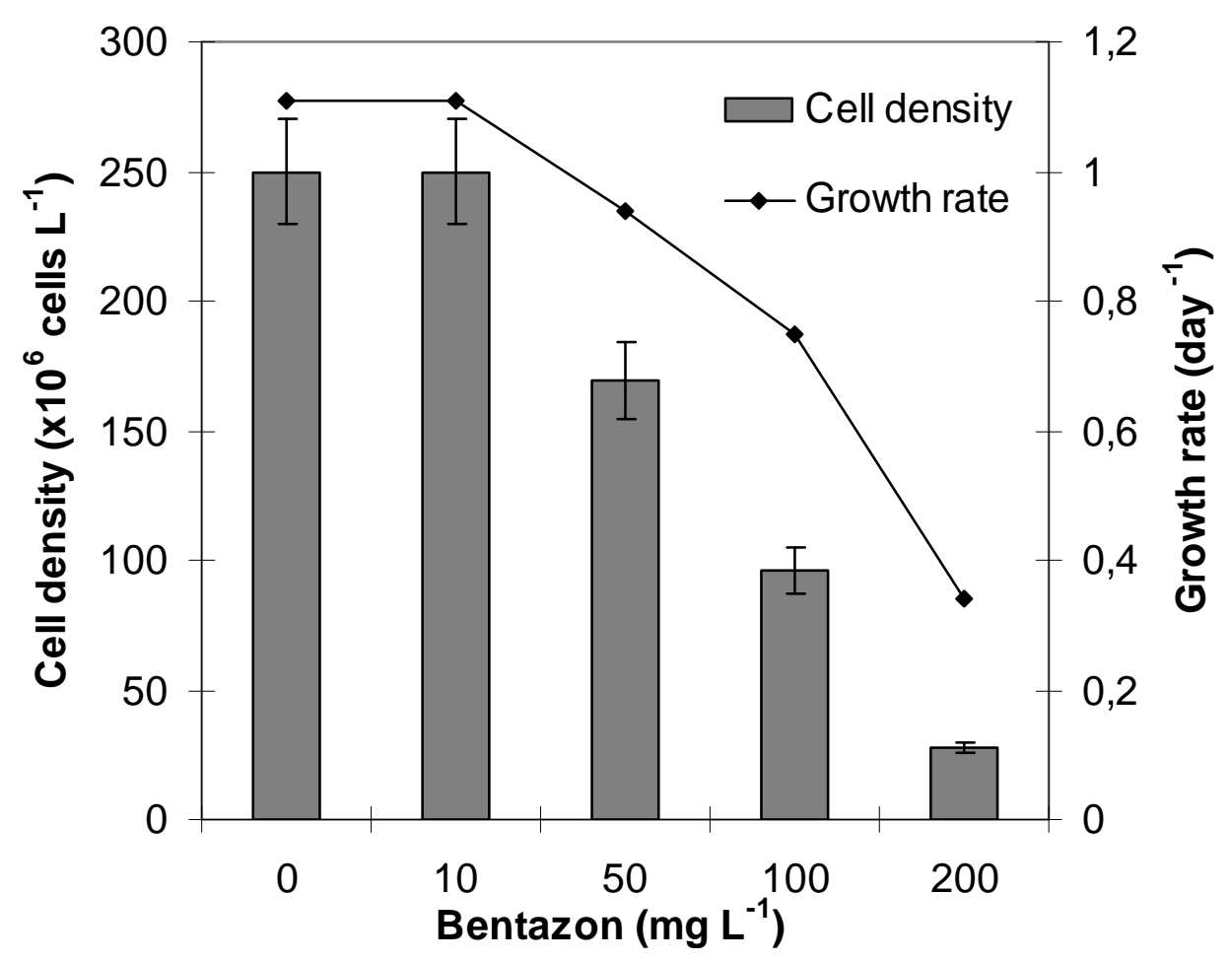

FIG. 1. Growth parameters of $C$. gracilis when exposed for 3 days to different concentrations of bentazon. Means of 3-6 independent experiments \pm SD. 


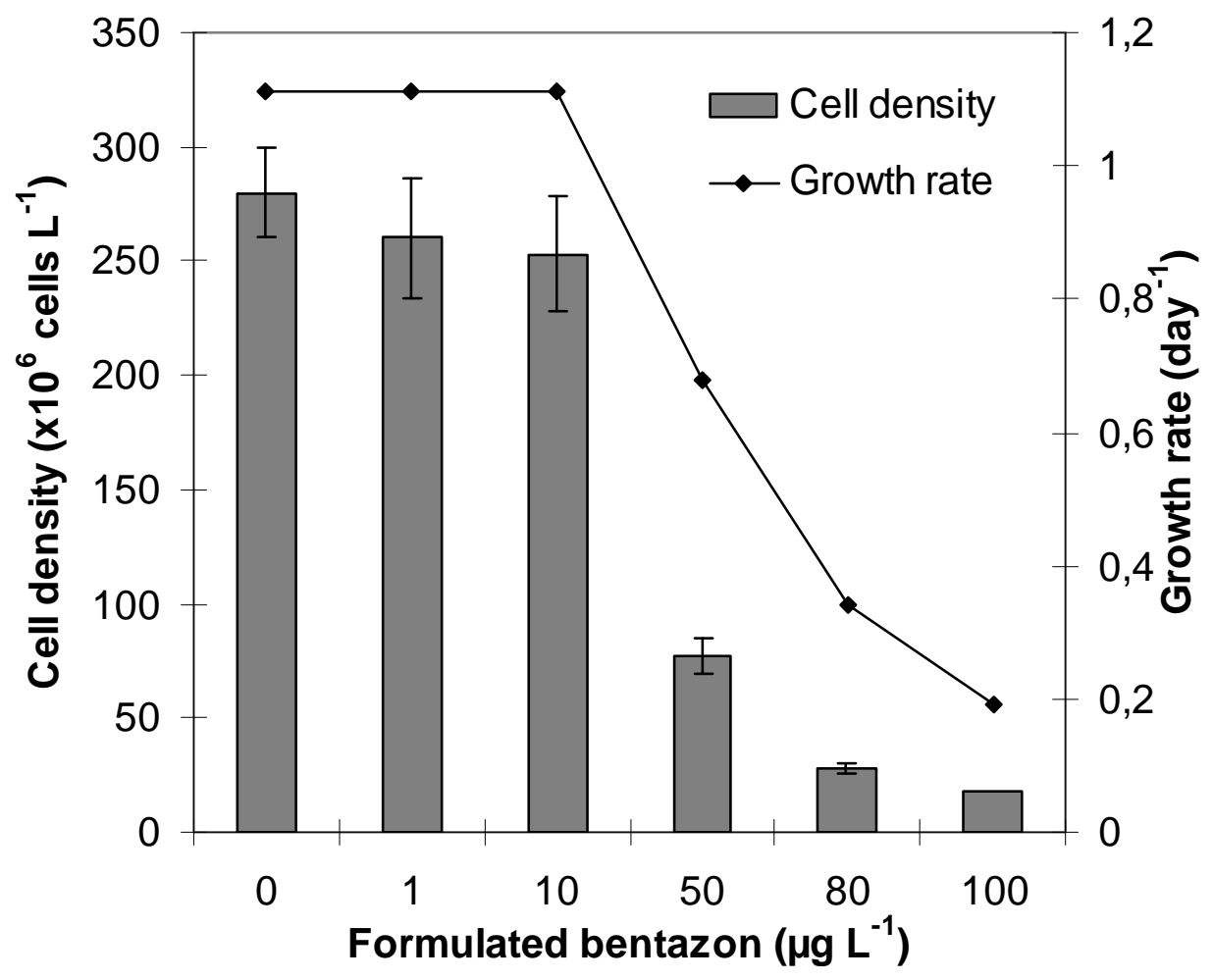

FIG. 2. Growth parameters of $C$. gracilis when exposed for 3 days to different concentrations of bentazon formulated product (Basamaïs). Means of 3-6 independent experiments \pm SD.

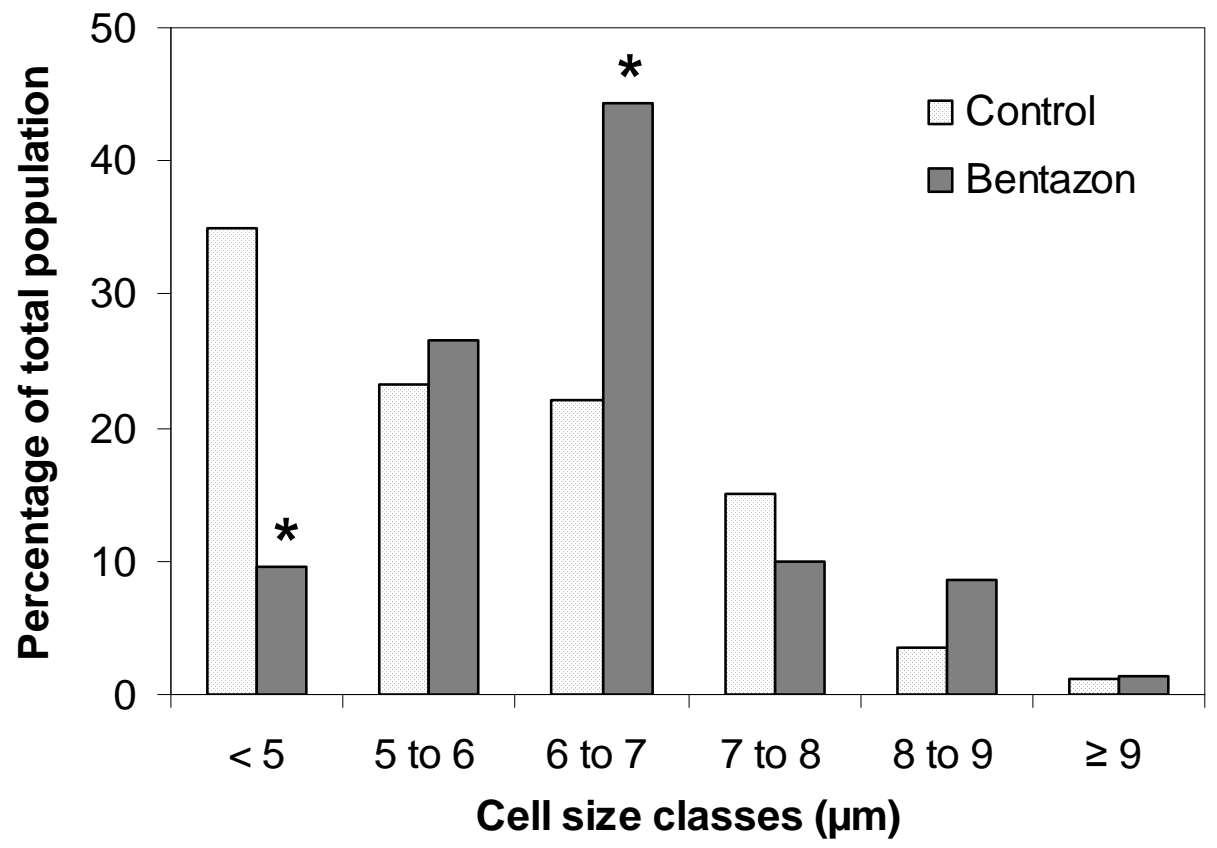

FIG. 3. Effect of $100 \mu \mathrm{g} \mathrm{L}^{-1}$ bentazon (Basamaïs) on the size of $C$. gracilis after 3 day culture. (Control : $\mathrm{n}=118$; Bentazon : $\mathrm{n}=127$ ). * indicates a value significantly different from the control at $P<0.05$. 

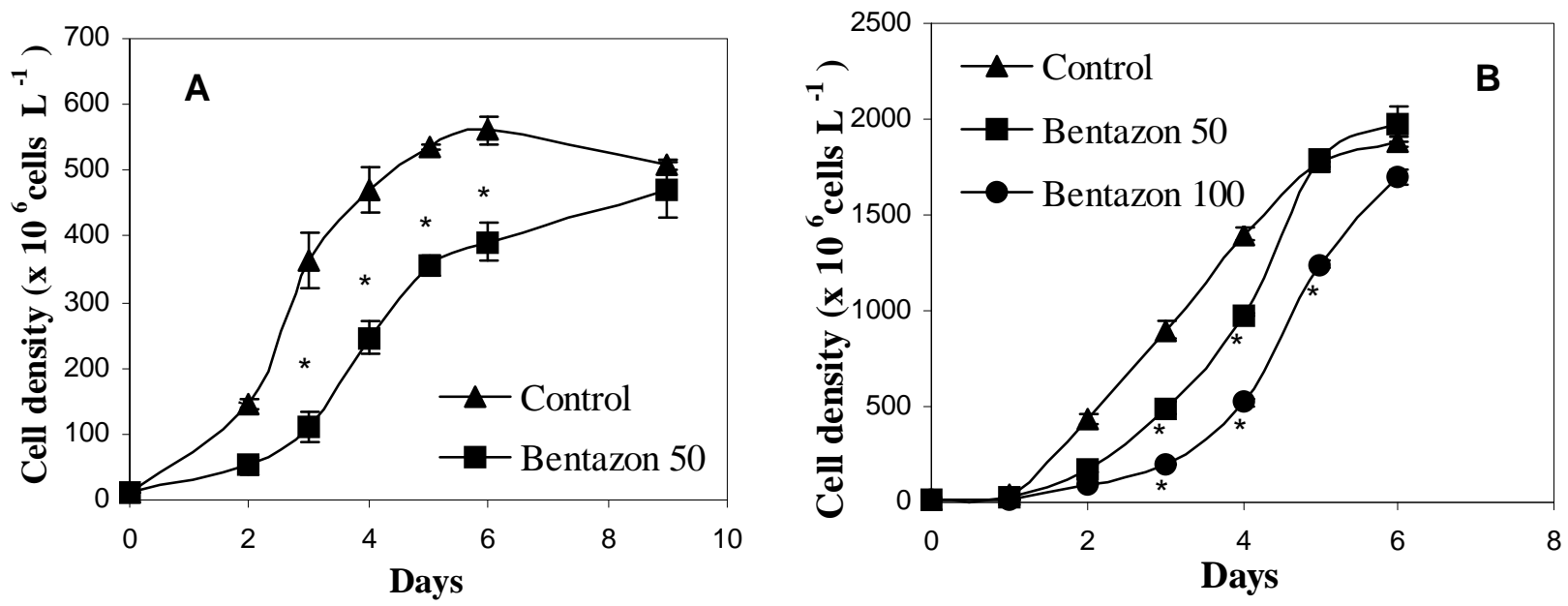

FIG. 4. Growth curves for $C$. gracilis when exposed to bentazon (Basamaïs). A : post winter conditions; $\mathrm{B}: \mathrm{f} / 2$ medium. * indicates a value significantly different from the control at $P<$ 0.05 .
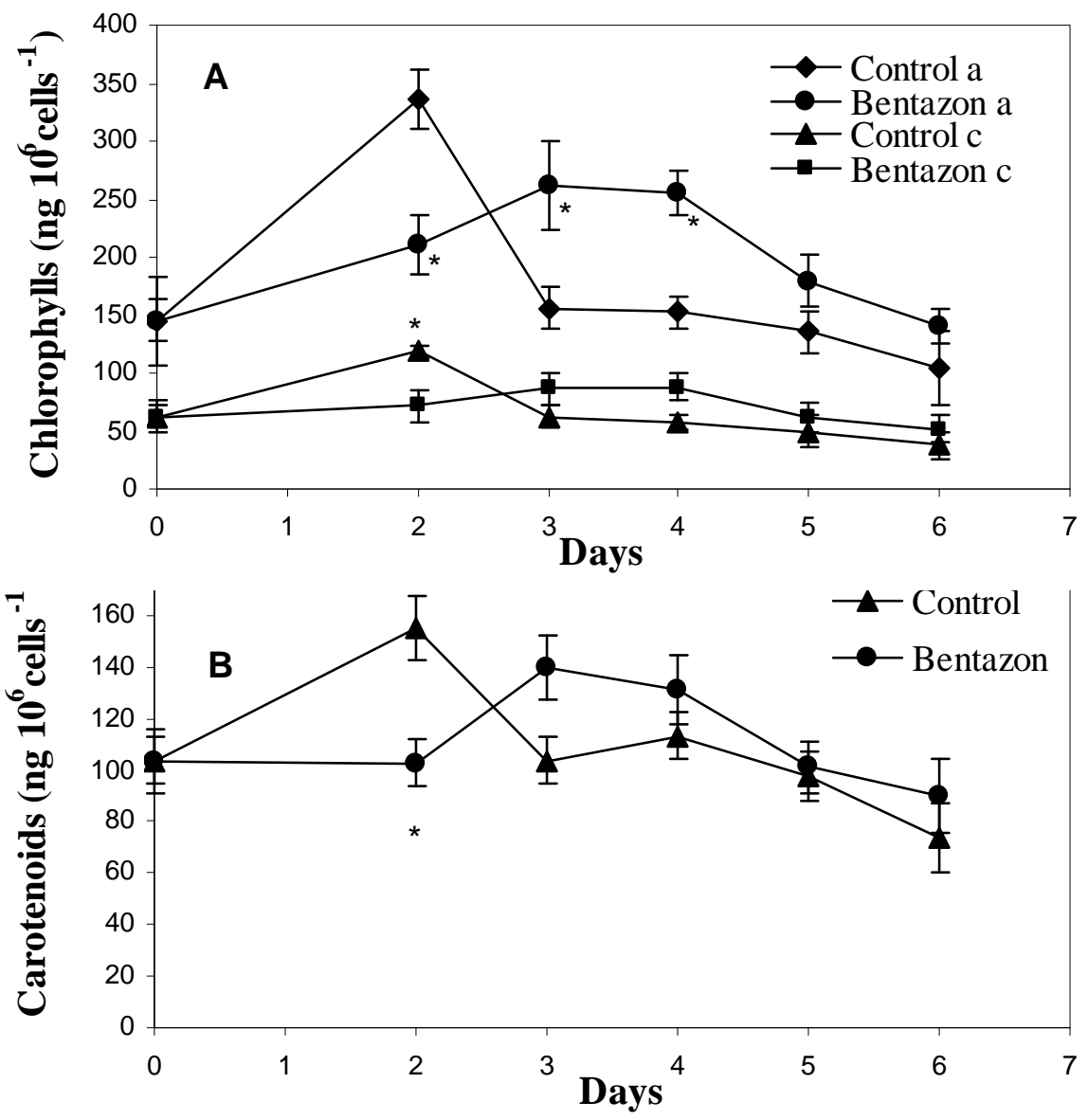

FIG. 5 A, B. Influence of $50 \mu \mathrm{g} \mathrm{L}^{-1}$ bentazon (Basamaïs) on pigment content of $C$. gracilis grown in a post winter medium. * indicates a value significantly different from the control at $P$ $<0.05$. A : chlorophylls a and c; $\mathbf{B}$ : carotenoids 


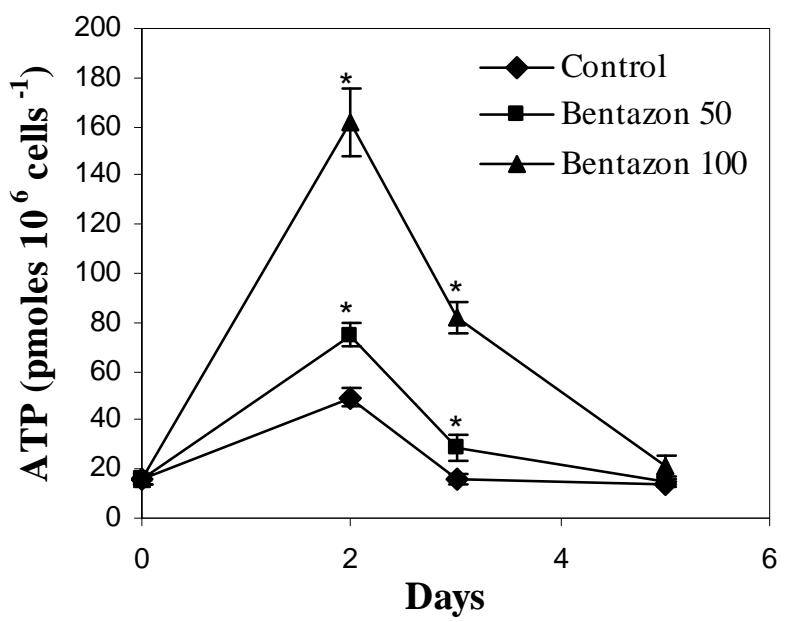

FIG. 6. Influence of 50 and $100 \mu \mathrm{g} \mathrm{L}^{-1}$ bentazon (Basamaïs) on the ATP content of $C$. gracilis grown in a post winter medium. * indicates a value significantly different from the control at $P$ $<0.05$. 